DOI: $\square$ https://doi.org/10.15407/techned2020.01.033

\title{
EFFICIENT OPERATING CONDITIONS OF INDUCTION MOTORS FOR PISTON COMPRESSORS WITH FREQUENCY REGULATION
}

Journal

Publisher

ISSN

Issue

Pages
Tekhnichna elektrodynamika

Institute of Electrodynamics National Academy of Science of Ukraine 1607-7970 (print), 2218-1903 (online)

No 1, 2020 (January/February)

$33-39$

\section{Authors}

O.V. Bibik ${ }^{\star}$, I.V. Golovan ${ }^{\star *}$, O.M. Popovych ${ }^{\star * *}$, Y.V. Shurub***

1. Institute of Electrodynamics of the National Academy of Sciences of Ukraine,

pr. Peremohy, 56, Kyiv, 03057, Ukraine,

e-mail: bibik@ied.ua

* ORCID ID : https://orcid.org/0000-0002-6236-6732

** ORCID ID : https://orcid.org/0000-0002-5250-6981

*** ORCID ID : https://orcid.org/0000-0002-9238-5782

**** ORCID ID : https://orcid.org/0000-0002-2735-4613

\section{Abstract}

The influence of periodic load on pulsations of electromagnetic torque and rotational speed, the losses and the efficiency of frequency-controlled induction motors for single-cylinder piston compressors are investigated using computer modeling. The region of critical reduction of motor efficiency when changing the frequency and supply voltage and the loading degree are determined using the criterion of heavy quasi-static regimes. References 16, figures 7, tables 2 .

Key words: induction motors, frequency control, single-cylinder piston compressors, pulsations, efficiency. 
The work was carried out according to governmental project «Scientific bases and tools for complex design synthesis of induction machines of energy-efficient and resource-saving electromechanical systems» (state registration number 0117U007715).

\section{References}

1. Bibik O.V. Grounding of the approaches to design of induction motors with variable load. Bull etin of NTU KhPl. Series: Electric machines and electromechanical energy conversion . 2019. No 4. (1329). Pp. 94-98. (Ukr) DOI:

https://doi.org/10.20998/2409-9295.2019.4.14

2. Bibik O.V., Popovych O.M., Shevchuk S.P. Power effective modes of electromechanical system for pump installation of high-rise building. Tekhnichna Elektrodynamika. 2016. No 6. Pp. 38-45. (Ukr)

tps://doi.org/10.15407/techned2016.05.038

3. Popovych O.M., Bibik O.V. Search and evaluation of ways to increase the energy efficiency for monoblock pump by complex design. Bulletin of NTU KhPI. Series: Electric machines and electromechanical energy conversion (1281). Pp. 79-82. (Ukr)

4. Bukaros A.Y., Romchuk N.O. Bukaros V.N. Adaptive control system compressor for electric drive. Automation technological and business-processes. 2014. Vol. 6. No 4. Pp. 84-90. (Rus) DOI:

https://doi.org/10.15673/2312-31

$\underline{25}$

5. Voyteh V.A. Frequency control of speed of induction motors for compressors of household refrigerators. Problems of modern electrical engineering. Tekhnichna Elektrodynamika. 2004. Vol. 3. Pp. 61-62. (Rus)

6. Hou X., Gu Z., Gao X., Feng S., Li Y. Analysis of efficiency and power factor of reciprocating compressor unit under variable-frequency and variable-conditions. International Compressor Engineering Conference at Purdue , USA. July 14-17, 2008. Pp 1-7. DOI:

https://docs.lib.purdue.edu/icec/1878

7. Binneberg, P., Kraus, E., Quack H. Reduction In Power Consumption Of Household Refrigerators By Using Variable Speed Compressors. International Refrigeration and Air 
Conditioning Conference

, USA. 2002.

Pp. 1-9. DOI:

ttp://docs.lib.purdue.edu/iracc/615

8. Jakobsen A., Rasmussen B. Energy optimization of domestic refrigerators Major energy saving by use of variable speed compressors and evaporator fans. International Appliance Manufacturing

No 2. Pp. 105-109.

9. Monasry J.F., Hirayama T., Aoki T., Shida S., Hatayama M., Okada M. Development of large capacity and high efficiency rotary compressor. International Compressor Engineering

Conference at Purdue

DOI:

. USA. 2018. Pp. 1-10.

https://docs.lib.pur

due.edu/icec/2576

10. Huang P. PD Compression: A Quasi-Static or Dynamic Process? Purdue International

Compressor Engineering Conference

, July 14-17, USA. 2014. Pp. 1-11. DOI:

http://docs.lib.purdue.edu/icec/2259

11. Akimov L.V., Kotlyarov V.O., Litvinenko D.G. Dynamic parameters of induction motors for frequency-controlled drives. Electric engineering \& Electromechanics. 2011. No 3. Pp. 10-14. (Rus)

12. Kravchik A.E., Shlaf M.M., Afonin V.I., Sobolenskaia E.A. Induction motors of 4 A series. Moskva: Energo-atomizdat, 1982. 504 p. (Rus)

13. Popovych O.M., Golovan I.V. Detail analysis of operating conditions of induction motors as a part electromechanotronic systems using equivalenting of field models by electrical circuits. $T e$ khnic

hna Elektrodynamika

. 2014. No 5. Pp. 113-115. (Ukr)

14. Morozyuk L.I., Morozyuk T.V., Yastrebova L.V. Designing of a piston compressor for refrigerating machines and heat pumps. Odessa: OGAKh, 2003. 75 p. (Rus)

15. Popovych O.M., Golovan I.V. Determination and study of power factor for

electromechanotronic systems with induction motors. Tekhnichna Elektrodynamika. 2014. No 5. Pp. 113-115. (Ukr)

16. Volkov I.V. A new concept for building power circuits of frequency-controlled asynchronous drives. Tekhnichna Elektrodynamika. 1999. No 4. Pp. 21-26. (Rus) 
Pif. 